\title{
PHENOTYPIC PLASTICITY IN Passiflora suberosa L.(PASSIFLORACEAE): INDUCTION AND REVERSION OF TWO MORPHS BY VARIATION IN LIGHT INTENSITY
}

\author{
BARP, E. A. ${ }^{1,2}$, SOARES, G. L. G. ${ }^{3}$, GOSMANN, G. ${ }^{4}$, \\ MACHADO, A. M. ${ }^{4}$, VECCHI, C. ${ }^{5}$ and MOREIRA, G. R. P. ${ }^{6}$ \\ ${ }^{1}$ PPG Ecologia, UFRGS, Av. Bento Gonçalves, 9500, CEP 91501-970, Porto Alegre, RS, Brazil \\ ${ }^{2}$ Universidade do Contestado, Rua Victor Sopelsa, 3000, CEP 89700-000, Concórdia, SC, Brazil \\ ${ }^{3}$ Departamento de Botânica, UFRGS, Av. Bento Gonçalves, 9500, CEP 91501-970, Porto Alegre, RS, Brazil \\ ${ }^{4}$ Faculdade de Farmácia, UFRGS, Av. Ipiranga, 2752, CEP 90610-000, Porto Alegre, RS, Brazil \\ ${ }^{5}$ Instituto de Biociências, USP, Rua Matão, 234, CEP 05508-900, São Paulo, SP, Brazil \\ ${ }^{6}$ Departamento de Zoologia, UFRGS, Av. Bento Gonçalves, 9500, CEP 91501-970, Porto Alegre, RS, Brazil \\ Correspondence to: Gilson Rudinei Pires Moreira, Departamento de Zoologia, Instituto de Biociências, UFRGS, \\ Av. Bento Gonçalves, 9500, CEP 91501-970, Porto Alegre, RS, Brazil, e-mail: gilson.moreira@ufrgs.br
}

Received March 5, 2003 - Accepted February 10, 2005 - Distributed August 31, 2006

(With 6 figures)

\begin{abstract}
Leaf morphology may vary considerably even within a branch of Passiflora suberosa plants. Leaves are of a typical green type in shaded areas, but in open fields turn into violet, and apparently have greater thickness and trichome density. The proximate causes and the adaptive meaning, if any, for the existence of the violet morph are still unknown. By cultivating P. suberosa clones under two light regimes (total and partial exposure to sunlight), we consecutively induced (first year) and then reversed (second year) the appearance of the violet morph. We evaluated the corresponding changes in morpho-anatomic and chemical leaf characteristics. Plants that were grown under partial sunlight had a greater size and did not alter their green color, but those grown under total sunlight changed into violet, were smaller in size and their leaves were tougher, thicker, and had a greater number of trichomes. The violet morph had increased anthocyanins and phenolic derivatives. It also showed cellular hypertrophy, a greater number of cell layers in the mesophyll, and a lignified pericycle. Since these morphs are interchangeable by changing light conditions, we inferred that they are not determined by genotypic diversity, but are mainly a result of a physiological response to light stress, and thus part of $P$. suberosa phenotypic plasticity.
\end{abstract}

Keywords: anthocyanins, leaf morphology, light stress, passion vines, phenolic derivatives.

\section{RESUMO \\ Plasticidade fenotípica em Passiflora suberosa L. (Passifloraceae): indução e reversão de duas formas pela variação na intensidade luminosa}

A morfologia das folhas de Passiflora suberosa pode variar consideravelmente mesmo dentro dos ramos de um dado espécime. P. suberosa ocorre tipicamente em áreas sombreadas e as folhas são verdes. Porém, em áreas abertas, onde há maior incidência de luz solar, as folhas são de coloração roxa, aparentemente mais duras e com grande densidade de tricomas. As possíveis causas e o significado adaptativo da manifestação destas características ainda são desconhecidas. Com base no cultivo de clones de P. suberosa sob dois regimes de luz solar (incidência total e parcial), nós consecutivamente induzimos (primeiro ano) e então revertemos (segundo ano) o aparecimento da forma roxa. As mudanças nas características morfológicas e químicas das formas verde e roxa foram avaliadas. As plantas que foram cultivadas sob incidência parcial de luz solar apresentaram maior tamanho dos ramos e não alteraram a cor verde das folhas. As plantas 
que foram cultivadas sob incidência total dos raios solares apresentaram coloração roxa, maior dureza, espessura e pilosidade. A forma roxa apresentou alto teor de antocianinas e derivados fenólicos. As plantas exibiram hipertrofia celular, maior número de camadas celulares no mesofilo e lignificação do periciclo. Considerando que as formas são intercambiáveis perante a mudança na intensidade luminosa, nós inferimos que elas não resultam da diversidade genotípica, mas sim de uma resposta fisiológica ao estresse luminoso e, dessa forma, parte da plasticidade fenotípica de P. suberosa.

Palavras-chave: antocianinas, derivados fenólicos, estresse luminoso, maracujás, morfologia foliar.

\section{INTRODUCTION}

Leaves of the cork-barked passion flower, Passiflora suberosa Linnaeus are known to vary considerably in shape, degree of pubescence and toughness (Killip, 1938; Sacco, 1980). These morphological variations can be observed either between or within populations, and even in a given branch of a $P$. suberosa plant. Our preliminary observations in several P. suberosa populations from Rio Grande do Sul State showed that leaves also vary enormously in color, from green to a variety of violet shades. Typical leaves of the former type are found on plants located under the forest canopy and of the latter, undescribed type, on plants from open fields, which are apparently also associated with greater pubescence and toughness. Studies carried out by Finkler et al. (1996) indicated that these two $P$. suberosa forms are linked to genotypic diversity.

In contrast, several studies have demonstrated that variation in light intensity can induce phenotypic variation in plants (e.g., Boardman, 1977; McLaren and Smith, 1978; Fetcher et al., 1987; Ackerly, 1997). In general, when located in unshaded areas, under high light intensity, leaves show greater toughness and trichome density. Moreover, plants under light stress can change nutrient contents in their leaves (Mattson, 1980; Jurik et al., 1982), as well as activate secondary metabolite synthesis such as coumarins (Berenbaum, 1991) and anthocyanins (Skaltsa et al., 1994). Anthocyanins are broadly found on angiosperm leaves and flowers, where they act in photoprotection (Gould et al., 1995; Lee \& Collins, 2001; Lee \& Gould, 2002; Steyn et al., 2002).

We tested the hypothesis that the P. suberosa violet form is induced by light intensity, which is greater for plants that are located in open fields, and thus being physiologically determined as part of $P$. suberosa phenotypic plasticity. We induced and reversed the appearance of the violet form by cultivating $P$. suberosa clones under two light regimes, while evaluating changes in morphoanatomical and chemical leaf characteristics.

\section{MATERIAL AND METHODS}

\section{Plant material}

P. suberosa seedlings $(\mathrm{n}=70)$ were collected at the Estação Experimental Águas Belas, Viamão County and Horto Florestal Barba Negra, Barra do Ribeiro County, Rio Grande do Sul State (RS), southern Brazil ( $\left.30^{\circ} 23^{\prime} \mathrm{S} ; 51^{\circ} 12^{\prime} \mathrm{W}\right)$. They were transplanted into plastic pots containing local soil and cultivated under outdoor conditions at the Zoology Department of the Universidade Federal do Rio Grande do Sul, Porto Alegre City, RS, following methodology described in MugrabiOliveira \& Moreira (1996). In the first year (induction experimental phase; from December 1998 to February 1999), plants were randomly distributed into two treatments (35 replicates/ treatment): 1) total and 2) partial exposition $(50 \%)$ to sunlight (Fig. 1). We covered the plants in treatment two with a fine plastic mesh, built for $50 \%$ retention of sunlight $\left(\mathrm{Fresal}^{\circledR}\right)$ to achieve partial exposure to solar radiation. The same plants were used during the second year (reversion experimental phase; from December 1999 to February 2000), and treatments were switched. At the beginning of each phase, all branches were cut off at $10 \mathrm{~cm}$ from the soil, to assure that all leaves developed under the adopted light experimental treatments.

\section{Morphological and anatomical features}

Twenty plants randomly selected from each treatment, during induction and reversion experimental phases were analyzed. Internode and total branch length, leaf number per branch, and area of the basal leaf (oldest leaf) were measured every 14 days over an 84-day period. The leaf area 


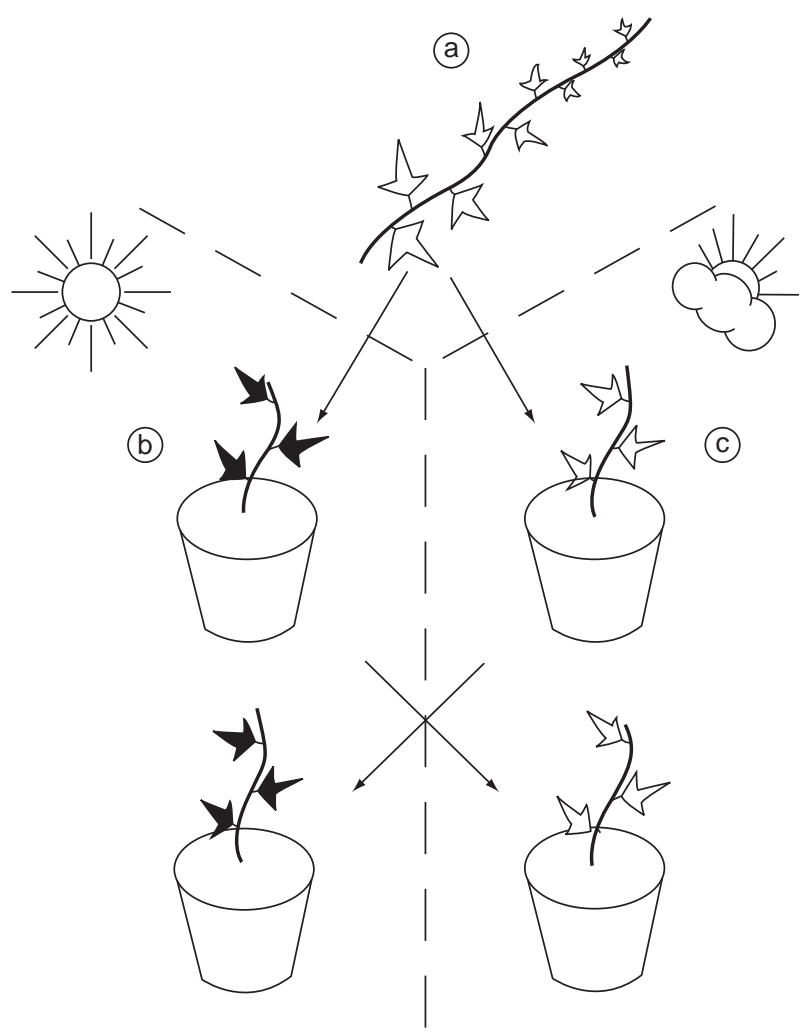

Fig. 1 - Experimental scheme adopted for outdoor cultivation of field-collected Passiflora suberosa plants during phases of induction of violet phenotype (full leaves) and corresponding reversion into the green phenotype (open leaves). a) Field-collected plants; b) maintained under total sunlight; and c) maintained under partial (50\%) sunlight. Arrows indicate the pathway of a given plant during the two sunlight regimes.

was determined by hand copying leaves on paper, cutting them off and measuring them with a Li-Cor ${ }^{\circledR}$ LI 3100 leaf area meter. Leaf width, pubescence and toughness were evaluated at the end of each experimental phase, using the first and seventh leaves of each branch. During the reversion phase, at the same time interval, variation in color was also quantified by comparing that of $P$. suberosa plant structures to those existing on color plates proposed by Villalobos \& Villalobos (1947).

Leaf pubescence, thickness and toughness were quantified at the end of each experimental phase. The number of trichomes was used as a measure of pubescence. Trichomes within a $1-\mathrm{mm}^{2}$ area, located in the central region of the abaxial leaf surface, were counted under a Spencer ${ }^{\circledR}$ stereomicroscope equipped with an ocular grid. Leaf blade width was adopted as an indicative of leaf thickness, which was measured with a Spencer ${ }^{\circledR}$ microscope equipped with an ocular micrometer. Measurements were performed on transverse leaf view sections. These were handmade with a razor blade on the median region of $P$. suberosa leaves. They were temporarily mounted on tap water in micro concavity slides. Leaf toughness was also obtained upon the median leaf region, by using a laboratory built penetrometer, modified from Feeny (1970).

Leaf epidermis was dissociated with $50 \%$ aqueous solution of commercial sodium hypochlorite and stained with safranin (Johansen, 1940). Transverse sections of fresh leaf blades were hand made and stained with safranin and astrablau (Kraus et al., 1998). The anthocyanin location was determined in transverse and in frontal view sections of fresh violet colored leaves. 


\section{Anthocyanidin detection and total phenolic content}

Fresh ground samples $(5 \mathrm{~g})$ of both forms of P. suberosa leaves were hydrolyzed with $20 \mathrm{~mL}$ of $\mathrm{HCl} 2 \mathrm{M}$ under reflux. After cooling and filtering, the hydrolysates were extracted two times with $5 \mathrm{~mL}$ of ethyl acetate and then with amyl alcohol $(2 \times 5 \mathrm{~mL})$ (Harborne, 1984). Both amyl alcohol fractions were submitted to two different paper chromatographic systems using Forestal (hydrochloric acid: acetic acid: water, 3:30:10, v/v) or BAW (n-butanol: acetic acid:water, 5:1:4, v/v; upper layer) as eluent Pelargonidin chloride $\left(\right.$ Roth $\left.^{\circledR}\right)$ was used as the reference substance. Solutions were stored under refrigeration in the dark. The amyl alcohol fraction from violet colored leaves was also submitted to preparative paper chromatography using Forestal as eluent. The pigment was extracted from the paper with methanol, concentrated to $5 \mathrm{~mL}$ and analyzed using a spectrophotometer Shimadzu ${ }^{\circledR}$ (UV-2201). The $\lambda_{\text {max }}$ between 400 and $700 \mathrm{~nm}$ of the pigment methanol solution was measured using the following as solvents: methanol, methanol plus 5 drops of $\mathrm{AlCl}_{3} 5 \%$, methanol plus 5 drops of $\mathrm{AlCl}_{3} 5 \%$ plus 3 drops of aqueous $\mathrm{HCl} 50 \%$ (v/v), according to Markham (1982) and Harborne (1984).

The total soluble phenols were determined in methanol extracts of green and violet leaves of intact $P$. suberosa branches $(\mathrm{n}=5$ plants, per morph type) by colorimetric assay, in which purified tannic acid was used as a standard (Waterman and Mole, 1994). The absorbance was measured at $725 \mathrm{~nm}$ in a spectrophotometer (Shimadzu ${ }^{\circledR}$ UV-220).

\section{Statistical analyses}

Data on P. suberosa plant growth (internode and total branch length, and basal leaf area) were compared among light treatments by using nonparametric Kolmogorov-Smirnov's tests. For the other comparisons, they were previously examined for normality and homocedasticity of variances using Kolmogorov-Smirnov and Bartlett's tests. Leaf pubescence, toughness and width were compared by using Student's t tests. The parametric and non-parametric tests followed procedures described in Sokal and Rohlf (1981) and Conover (1980), alpha $=0.05$. Measurements are given as mean \pm standard error, unless noted.

\section{RESULTS}

\section{Morphological and anatomical features}

The internode and total branch length, and basal leaf area were greater for plants grown under partial exposure to sunlight throughout both the induction and reversion phases (Fig. 2).

Leaves of those plants that were maintained under partial exposure to sunlight were green throughout the induction phase. Leaf color changed from green to violet on those plants under total exposure to sunlight (Figs. $3 a$ and $b$ ). Conversely, throughout the reversion phase, they changed back into green, and those that were green in the induction phase changed progressively into violet. Contrary to plants under partial exposure to sunlight, all tendrils, stems, petioles and stipules of plants under total exposure to sunlight were violet at the end of the reversion phase (Fig. 4). By covering a few leaves with perforated paper, it was shown that the appearance of the violet color occurs in a few days of exposure to sunlight, and that the corresponding color intensity can spatially vary within a single leaf, depending upon light intensity (Fig. 3c).

During both induction and reversion phases, leaf thickness and pubescence were greater on leaves of plants maintained under total exposure to light. Treatments did not differ regarding leaf toughness during the induction phase. However, it was greater on those plants maintained under total exposure to light in the reversion phase (Fig. 5).

$P$. suberosa green leaves presented epidermal cells with sinuous walls and two types of unicellular trichomes: aciculate and claviform (Fig. 6a). The claviform type was more frequent and occurred all over the leaf blade. Aciculate trichomes were nearly restricted to the margin of the leaf. However, there was a visible alteration in the distribution of aciculate trichomes, which could be found in all leaf blades on the violet type but not in the green (Figs. 6a and b).

When compared to green leaves, the ground tissue on the violet leaves presents cellular hypertrophy, especially on the palisade parenchyma (Fig. 6d). The violet colored leaves showed twocell thick layer palisade, while the green leaves had uniseriate palisade. The spongy parenchyma had cellular hypertrophy in the violet colored leaves, 

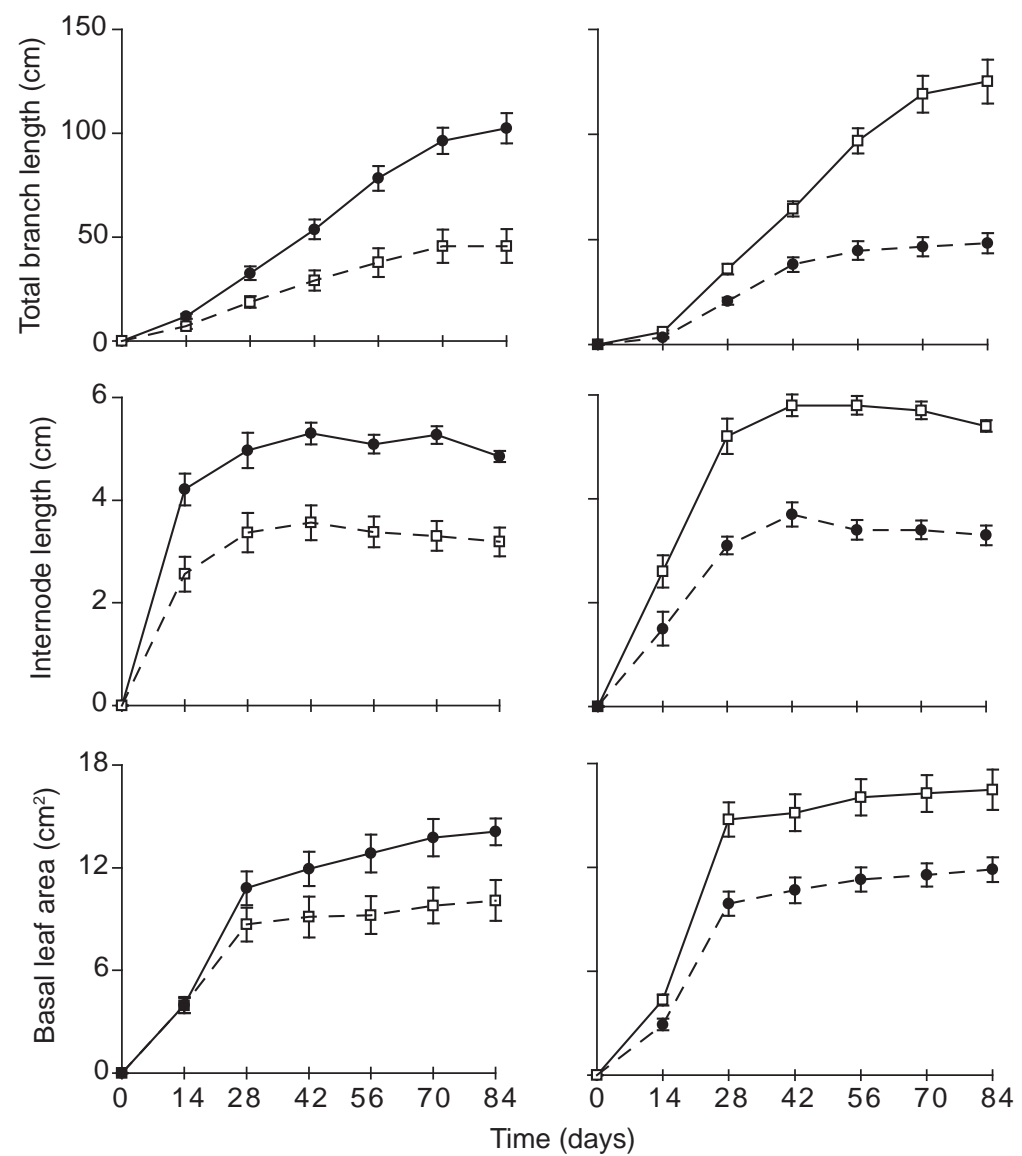

Fig. 2 - Induction (left) and reversion (right) of plant trait characteristics for Passiflora suberosa cultivated under total (broken lines) and partial (solid lines) exposure to sunlight. Identical signals (either open squares or full circles) represent the same individual plants that were used in the two phases. Curves for the three traits show statistical differences within a given experimental phase (Kolmogorov-Smirnov tests; $\mathrm{p}<0.001 ; \mathrm{n}=20$ plants per light regime).
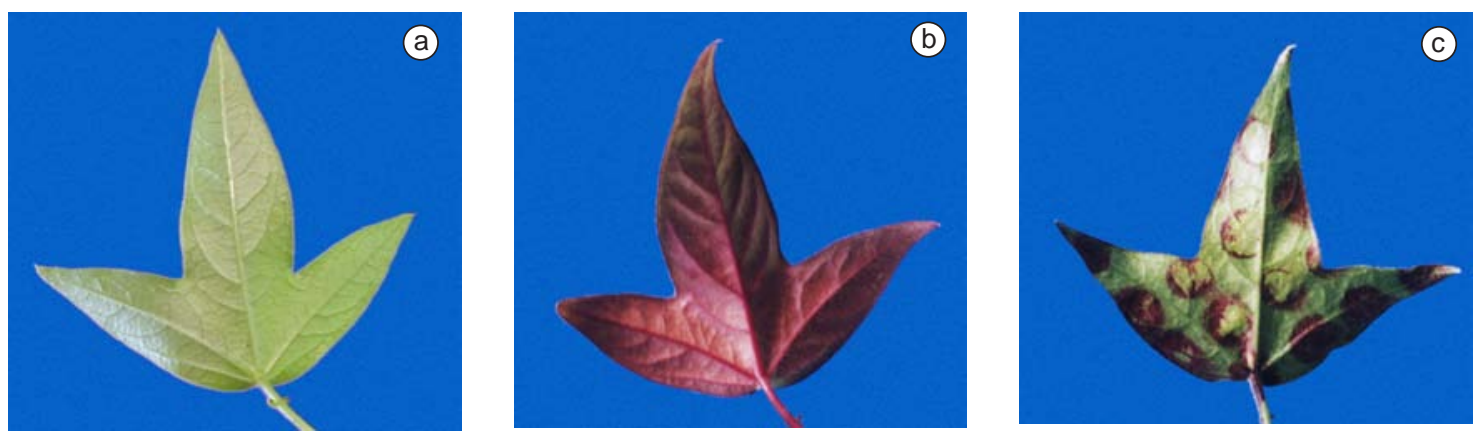

Fig. 3 - Passiflora suberosa leaves from plants cultivated under different sunlight regimes. a) green type, resulting from partial (50\%) incidence of sunlight; b) violet type, from total incidence of sunlight; and c) variegated type, obtained by covering the leaves with perforated paper, showing violet spots resulting from light incidence.

but not hyperplasy, thus keeping its five layers of cells on both leaf types (Figs. 6e and f). Regarding the vascular system, the architectural pattern of the species was not altered. The perycicle became lignified on the violet leaves (Figs. $6 g$ and $h$ ). There were anthocyanins only in the epidermal cells of 
(a)
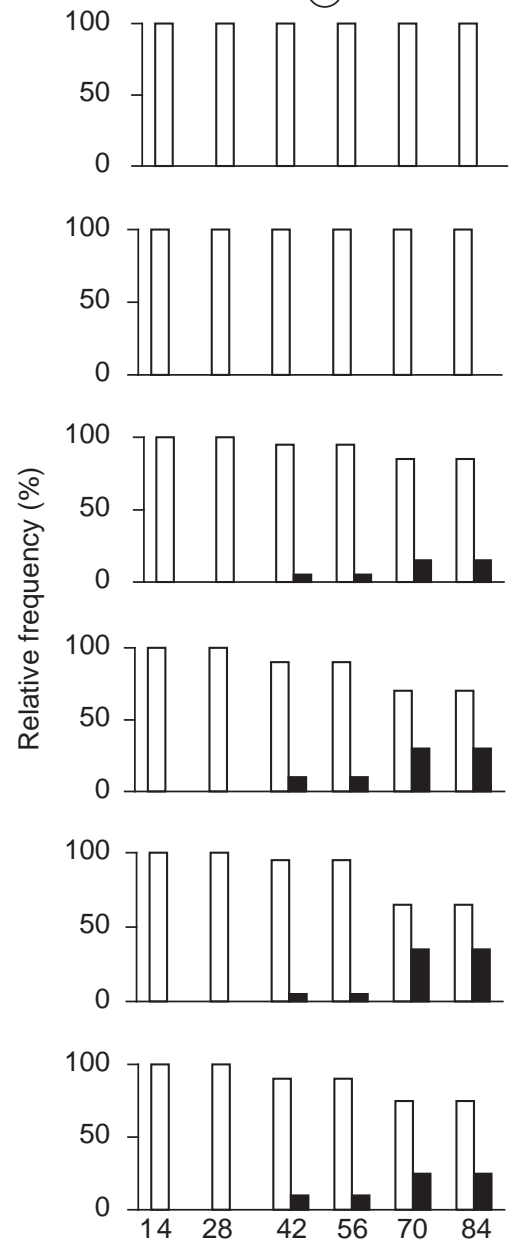

(b)
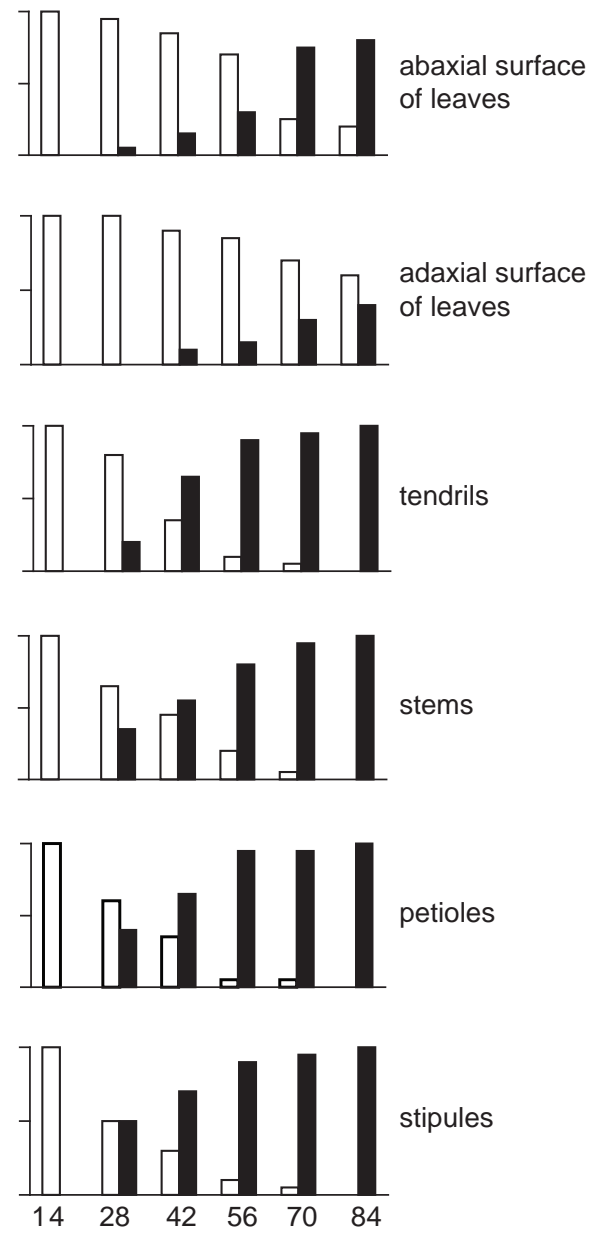

Fig. 4 - Temporal variation in color of branch structures on Passiflora suberosa plants during phase of reversion, under partial (left, a) and total (right, b) exposure to sunlight ( $\mathrm{n}=20$ plants per treatment).

violet colored leaves, as seen in the transverse sections (Figs. 6c and f).

\section{Anthocyanidin detection and total phenolic content}

Anthocyanidin derivatives were detected only in violet colored leaves. The amyl alcohol fraction from plants cultivated under partial exposition to sunlight did not present spots at the chromatographic systems used (Forestal and BAW). On the contrary, amyl alcohol fraction from plants cultivated under total exposure to sunlight presented one reddish spot (compound 1) with Rf 0.55 (using BAW) and Rf 0.52 (using Forestal) that turned into blue when using ammonia vapors under visible light.
Pelargonidin chloride presented one reddish spot with Rf 0.84 (BAW) and Rf 0.72 (Forestal) that also turned into blue when using ammonia vapors under visible light. Anthocyanin derivatives turn into blue when under alkaline $\mathrm{pH}$ (Harborne, 1984). Compound 1 was isolated by preparative paper chromatographic and its $\lambda_{\max }$ was measured under different experimental conditions using visible spectroscopy: $\lambda_{\max } 535(\mathrm{MeOH}), 574\left(\mathrm{AlCl}_{3}\right)$ and $536\left(\mathrm{AlCl}_{3} / \mathrm{HCl}\right)$. The chromatographic profile and visible absorption data of compound 1 are very similar to those from cyanidin derivatives (Harborne, 1984).

$P$. suberosa violet leaves grown under total sunlight clearly produced greater amounts of 
(a)
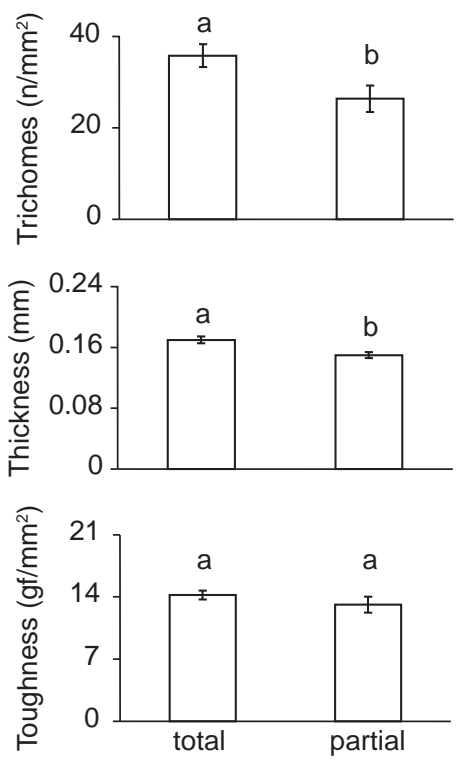

(b)
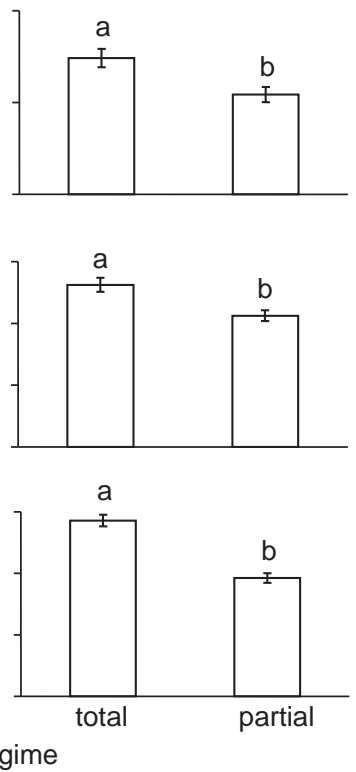

Fig. 5 - Variation on leaf characteristics of Passiflora suberosa plants grown under partial (50\%) and total exposition to sunlight, at the end of the induction (left, a) and reversion (right, b) phases. Bar followed by the same letters do not differ statistically (Student $\mathrm{t}$ tests; alpha $=0.05 ; \mathrm{n}=20$ plants per treatment; data for each plant represent the average for first and seventh leaves).

phenolic derivatives (average $=31 \pm 0.99 \mu \mathrm{g} / \mathrm{mg}$ ) when compared with leaves under partial incidence of light (average $=10 \pm 0.44 \mu \mathrm{g} / \mathrm{mg}$ ).

\section{DISCUSSION}

Light intensity variation induced changes in P. suberosa morphology. Plants that were grown artificially, under shade, were larger, and mantained a green leaf color. Those grown under full sunlight changed from green to violet. The latter also grew less, and had tougher and thicker leaves with a greater number of trichomes. These patterns did not seem to be determined mainly by genotypic diversity, since in a given plant these color patterns were interchangeable by light conditions. Finkler et al. (1996) pointed out the existence of genetic fixation for such morphological characters, and thus suggesting the existence of two $P$. suberosa morphs (green and violet). Contrary to their view we attribute this phenomenon mainly to a physiological response to light stress, and thus linking it to phenotypic plasticity (sensus Schlichting \& Pigliucci, 1998).
Plants under shade often have greater growth and petiole elongation rates than those located in open areas (McLaren and Smith, 1978; Morgan \& Smith, 1981; Fetcher et al., 1987). Passion vines are typical umbrophilic plants, which are expected to have considerable energy loss during photosynthesis under light stress, and thus grow proportionally to a reduced size (Larcher, 1995). Leaf thickness in $P$. suberosa, supposedly, is directly associated with how developed the palisade and spongy mesophyll are, which are greater under light exposition, thus leading to thicker leaves (e.g. Boardman, 1977; Larcher, 1995; Rôças et al., 2001). On P. suberosa leaves grown under direct sunlight, these anatomical features are combined with a thicker epidermis and a sclerenchyma characterized by a lignified pericycle. High leaf pubescence of $P$. suberosa violet leaves are supposedly related to light stress, associated either with leaf surface protection from sunlight, by increasing light reflectance, or with prevention of excessive evapotranspiration (Ehleringer \& Mooney, 1978). 

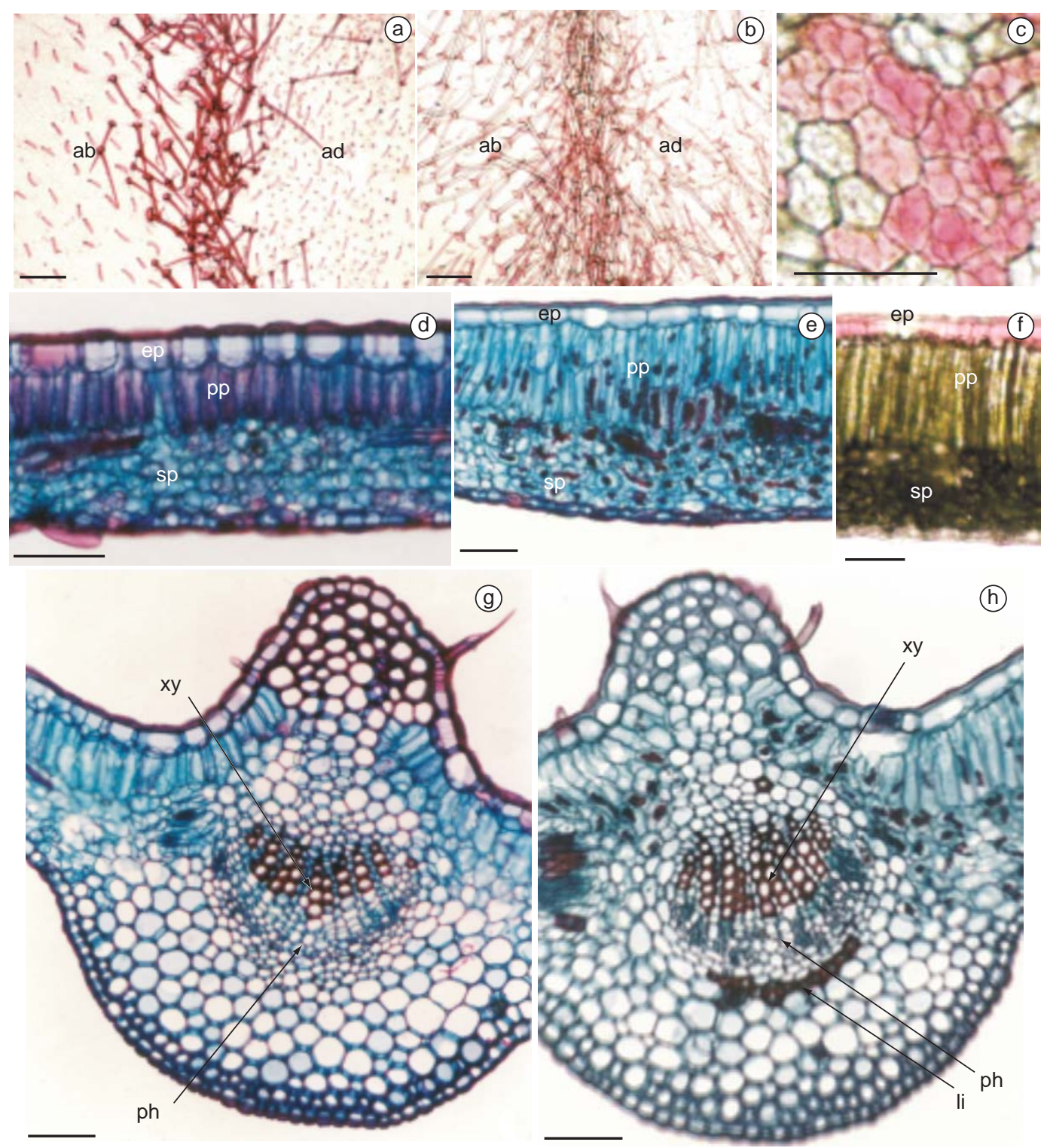

Fig. 6 - Anatomical features of Passiflora suberosa leaf. Frontal view of the epidermis on the edge of green (a) and violet (b) forms, showing abaxial and adaxial surfaces; epidermic portion of violet leaf type showing anthocyanins in adaxial surface (c); cross sections of green leaf lamina (d) and violet (e) leaf lamina; midvein of green (g) and violet (h) leaves. An additional cross section of fresh leaf lamina showing occurrence of anthocyanins in the epidermic cells is shown in F. ad: adaxial portion; ab: abaxial portion; ep, epidermis; li, lignified endodermis; pp, palisade parenchyma; ph, phloem; sp, spongy parenchyma; xy, xylem. Bars $=200 \mu \mathrm{m}$.

The presence of anthocyanins that gives the violet color for $P$. suberosa leaves under total sunlight is also associated with variation in color of several plant parts and tissues (Harborne, 1993; Chalker-Scott, 1999). Their production is a response to light stress that leads to an increase in photoinhibition of the photosynthetic apparatus and corresponding damage resulting from UV light incidence (Gould et al., 1995). The mechanism of light-induced anthocyanin biosynthesis is related to the transcription activation by UV light of phenylalanine ammonia lyase (PAL), the 
key enzyme of the shikimate pathway (Jones, 1984). Most of the published data concerning anthocyanin induction suggests that UVB is the only photoinducer of these pigments, while their relative amounts are modulated by phytochrome in response to wavelengths in the far-red regions (Chalker-Scott, 1999). Our results provide experimental evidence regarding anthocyanin production in response to light incidence variation. Indeed, we were able to induce the violet color in a few days on localized leaf regions (spots), by covering them with paper containing holes, followed by direct exposure to light. This result suggests that the photoreceptor related to anthocyanin biosynthesis in $P$. suberosa is very sensitive to light induction. The activation of PAL in response to light stress could also explain the increase in total phenolic content and lignin production on violet leaves of $P$. suberosa, since the same biosynthetic pathway produces these chemical compounds (Wink, 1999).

Thus, we linked $P$. suberosa plasticity to its ability to adjust leaf anatomy according to environmental variation related to light intensity, which could partly account for its commonness in both shaded and open areas in southern Brazil. The corresponding reaction norms remain to be determined (sensus Scheiner, 1993; Scheiner and Callahan, 1999; Cardoso and Lomônaco, 2003). Depending upon what direction natural selection, if any, takes in such populations (e.g., occurrence of disruptive selection), formation of P. suberosa ecotypes may be favored (sensus Via and Lande, 1985; Thompson, 1991), which should be explored further. As pointed out by Rôças et al. (2001), ecological plasticity has been rarely taken into account as an important component responsible for biodiversity in the tropics.

It is unknown what the ecological implications of variation in $P$. suberosa leaf color and other associated phenotypic characteristics are. The increase of phenolic compounds in P. suberosa leaves mediated by light exposure could modulate the interactions of this plant with associated biota. The relation between the change of shikimate metabolites, represented by the increase of total phenolic content and anthocyanin biosynthesis, and the capacity of $P$. suberosa defend itself against biotic and abiotic stresses constitutes a hypothesis which deserves further studies. For example, giving a choice between green and violet leaves, females of Heliconius erato phyllis (Lepidoptera, Nymphalidae) whose larvae feed upon P. suberosa leaves, select the green type for oviposition, under both laboratory and field conditions (Barp, 2000). Heliconian butterflies are known to have a good sense of vision, including induced learning by color (Swihart, 1963, 1968, 1971; Swihart \& Gordon, 1971; Langer and Struwe, 1972). By offering paper painted leaves of different colours (including violet) for oviposition under insectary conditions, we were already able to demonstrate that females in this case cue on the oviposition substrate color itself (Barp, E. and Moreira, G. R. P. unpublished data). Thus, we interpret these findings as strong evidence that, by turning into the violet colored, $P$. suberosa plants located on an open area scape from herbivory using phenotypic differentiation.

Acknowledgments - The authors are especially grateful to an anonymous reviewer and Fábio R. Scarano (UFRJ) for criticisms and suggestions that substantially improved the final version of the manuscript. Financial support for this study came in part from Universidade do Contestado, Santa Catarina State, and from a CAPES Master Science scholarship granted to E. Barp. This is contribution number 502 from the Zoology Department of Federal University of Rio Grande do Sul, Brazil.

\section{REFERENCES}

ACKERLY, D., 1997, Allocation, leaf display, and growth in fluctuating light environments, pp. 231-264. In: F. A. Bazzaz \& J. Grace (eds.), Plant resource allocation. Academic Press, London, 303p.

BARP, E. A., 2000, Caracterização de duas formas de Passiflora suberosa Linnaeus (Passifloraceae) e seleção por Heliconius erato phyllis (Fabricius) (Lepidoptera: Nymphalidae). Unpublished Master Thesis. PPG Biologia Animal, Universidade Federal do Rio Grande do Sul. Porto Alegre, 92p.

BERENBAUM, M. R., 1991, Coumarins, pp. 221-249. In: G. A. Rosenthal \& M. R. Berenbaum (eds), Herbivores: their interactions with secondary plant metabolites. vol. 1, 2nd ed. Academic Press, London, 468p.

BOARDMAN, N. K., 1977, Comparative photosynthesis of sun and shade plants. Ann. Rev. Plant Physiol., 28: 355-377.

CARDOSO, G. L. \& LOMÔNACO, C., 2003, Variações fenotípicas e potential plástico de Eugenia calycina Cambess. (Myrtaceae) em uma área de transição cerradovereda. Revista Brasil. Bot., 26: 131-140.

CHALKER-SCOTT, L., 1999, Environmental significance of anthocyanins in plant stress responses. Photochem. Photobiol., 70: 1-9.

CONOVER, W. J., 1980, Practical nonparametric statistics. 2nd ed. John Wiley \& Sons, New York, 493p. 
EHLERINGER, J. R. \& MOONEY, H. A., 1978, Leaf hairs: effects on physiological activity and adaptive value to a desert shrub. Oecologia, 37: 183-200.

FEENY, P., 1970, Seasonal changes in oak leaf tannins and nutrients as a cause of spring feeding by winter moth caterpillars. Ecology, 51: 565-581.

FETCHER, N., OBERBAUER, S. F., ROJAS, G. \& STRAIN, B. R., 1987, Efectos del régimen de luz sobre la fotosíntesis y el crecimiento en plántulas de árboles de un bosque lluvioso tropical de Costa Rica. Rev. Biol. Trop., 35: 97-110.

FINKLER, C., FREITAS, L. B., BONATTO, S. L. \& SALZANO, F. M., 1996, Caracterização molecular de duas formas morfológicas de Passiflora suberosa (Passifloraceae). Braz. J. Genet., 19: 282.

GOULD, K. S., KUHN, D. N., LEE, D. W. \& OBERBAUER, S. F., 1995, Why leaves are sometimes red. Nature, 378: 241-242.

HARBORNE, J. B., 1984, Phytochemical methods: a guide to modern techniques of plant analysis, 2 nd ed. Chapman and Hall, London, 288p.

HARBORNE, J. B., 1993, Introduction to ecological biochemistry, 4th ed. Academic Press, London, 318p.

JOHANSEN, D. A., 1940, Plant microtechnique. McGraw-Hill. New York, 523p.

JONES, D. H., 1984, Phenylalanine ammonia-lyase: regulation of its induction, and its role in plant development. Phytochemistry, 23: 1349-1521.

JURIK, T. W., CHABOT, F. J. \& CHABOT, B., 1982, Effects of light and nutrients on leaf size, $\mathrm{CO}_{2}$ exchange, and anatomy in wild strawberry (Fragaria virginiana). Plant Physiol, 70: 1044-1048.

KILLIP, E. P., 1938, The american species of Passifloraceae. Publ. Field Mus. Nat. Hist. Bot. Ser. 19: 1-613.

KRAUS, J. E., SOUSA, H. C., RESENDE, M. H., CASTRO, N. M., VECCHI, C. \& LUQUE, R., 1998, Astra blue and basic fuchsin double staining of plant material. Biotec. Histochem., 73: 235-243.

LANGER, H. \& STRUWE, G., 1972, Spectral absorption by screening granules in the compound eye of butterflies (Heliconius). J. Comp. Physiol., 79: 203-212.

LARCHER, W., 1995, Physiological plant ecology. Springer Verlag, Berlin, 450p.

LEE, D. W. \& COLLINS, T. M., 2001, Phylogenetic and ontogenetic influences on the distribution of anthocyanis and betacyanis in leaves of tropical plants. Int. J. Plant Sci.,162: 1141-1153.

LEE, D. W. \& GOULD, K. S., 2002, Why leaves turn red. Am. Scientist, 90: 524-531.

MARKHAM, K. R., 1982, Techniques of flavonoididentification. Academic Press, New York, 113p.

MATTSON Jr, W. J., 1980, Herbivory in relation to plant nitrogen content. Ann. Rev. Ecol. Syst., 11: 119-161

McLAREN, J. S. \& SMITH, H., 1978, Phytochrome control of the growth and development of Rumex obstusifolius under simulated canopy light environments. Plant Cell. Environ., 1: 61-67.
MORGAN, D. C. \& SMITH, H., 1981, Control of development in Chenopodium album L. by shadelight: the effect of light quantity (total fluence rate) and light quality (red: far-red ratio). New Phytol., 88: 239-248.

MUGRABI-OLIVEIRA, E. \& MOREIRA, G. R. P., 1996, Size of and damage on shoots of Passiflora suberosa (Passifloraceae) influence oviposition site selection of Heliconius erato phyllis (Fabricius) (Lepidoptera, Nymphalidae. Revta bras. Zool. 13: 929-937.

RÔÇAS, G., SCARANO, F. R. \& BARROS, C. F., 2001, Leaf anatomical variation in Alchornea triplinervia (Spreng) Müll. Arg. (Euphorbiaceae) under distinct light and soil water regimes. Bot. J. Linn. Soc., 136: 231-238.

SACCO, J. C., 1980, Passifloraceae, pp. 1-130. In: Reitz R. (ed) Flora ilustrada catarinense. Herbário Barbosa Rodrigues, Itajaí. 130p.

SCHEINER, S. M., 1993, Genetics and evolution of phenotypic plasticity. Annu. Rev. Ecol. Syst., 24: 35-68.

SCHEINER, S. M. \& CALLAHAN, H. S., 1999, Measuring natural selection on phenotypic plasticity. Evolution, 53: 1704-1713.

SCHLICHTING, C. D. \& PIGLIUCCI, M., 1998, Phenotypic evolution: a reaction norm perspective. Sinauer Associates, Sunderland.

SKALTSA, H., VERYKOKIDOU, E., HARVALA, C., KARABOURNIOTIS, G. \& MANETAS, Y., 1994, UV-B protective potential and flavonoid content of leaf hairs of Quercus ilex. Phytochemistry, 37: 987-990.

SOKAL, R. R. \& ROHLF, F. J., 1981, Biometry. 2nd ed. W.H. Freeman and Company, New York, 859p.

STEYN, W. J., WAND, S. J. E., HOLCROFT, D. M. \& JACOBS, G., 2002, Anthocyanins in vegetative tissues: a proposed unified function in photoprotection. New Phytol, 155: 349-361.

SWIHART, C. A., 1971, Colour discrimation by the butterfly Heliconius charitonius Linn. Anim. Behav., 19: 156-164.

SWIHART, S. L., 1963, The nature of the electroretinogram of a tropical butterfly. J. Insect Physiol., 110: 547-562.

SWIHART, S. L., 1968, Single unit activity in the visual pathway of the butterfly Heliconius erato. J. Insect Physiol., 14: 1589-1601.

SWIHART, S. L. \& GORDON, W. C., 1971, Red photoreceptor in butterflies. Nature, 231: 126-127.

THOMPSON, J. D., 1991, Phenotypic plasticity as a component of evolutionary change. Trends Ecol. Evol., 6: 246-249.

VIA, S. \& LANDE, R., 1985, Genotype-environment interactions and the evolution of phenotypic plasticity. Evolution, 39: 505-522.

VILLALOBOS, D. C. \& VILlALOBOS, J., 1947, Atlas de los colores. Ateneo, Buenos Aires, 74p.

WATERMAN, P. \& MOLE, S., 1994, Analysis of phenolic plant metabolites. Blackwell Scientific Publications, London, 238p.

WINK, M., 1999, Biochemistry of plant secondary metabolism. Sheffield Academic Press, Sheffield. 358p. 